\section{The Euro Group and judicial protection: Has the Court of Justice created a loophole?}

Maastricht Journal of European and Comparative Law 202I, Vol. 28(6) 919-930 (C) The Author(s) 2021 (c) (i)

Article reuse guidelines: sagepub.com/journals-permissions DOI: 10.1 I77//023263X2| 1048602 maastrichtjournal.sagepub.com

(SAGE

\author{
Phedon Nicolaides
}

\begin{abstract}
The Court of Justice made legal history in Ledra Advertising when it found that the EU could incur non-contractual liability even for acts that formally fell within the intergovernmental sphere. In Chrysostomides, however, by ruling that the Euro Group is not an EU 'institution', the Court has made it largely impossible for individuals to obtain judicial protection. The decisions of the Council that give effect to agreements in the Euro Group can be drafted in innocuous and general language, minimizing or even expunging any liability. The powers of the Commission to act against such agreements in the Euro Group are also unclear and probably non-existent.
\end{abstract}

\title{
Keywords
}

Euro Group, article 340 TFEU, non-contractual liability, judicial protection

\section{Introduction}

On 16 December 2020, the Court of Justice ruled in a landmark judgment that the Euro Group was not an EU institution or an entity established by the Treaties. Consequently, the Euro Group could not be held liable under Article 340(2) TFEU.

If the Euro Group is not liable, the question that arises immediately is how individuals can avail themselves of judicial protection from actions of the Euro Group. The Court of Justice has provided an answer to this question. Individuals who are harmed can seek redress via the liability of the Council, when it gives effect to agreements struck in the Euro Group, or the Commission, if it fails to prevent agreements that may violate EU law.

University of Maastricht, Maastricht, Netherlands

\section{Corresponding author:}

Phedon Nicolaides, University of Maastricht, Maastricht, Netherlands

Email: phedon.nicolaides@maastrichtuniversity.nl 
The purpose of this short article is to argue that, regardless of whether one agrees or not with that ruling of the Court of Justice, the judgment may in fact have weakened judicial protection of individuals because it may be impossible to prove the indirect liability of the Council or Commission for agreements reached within the Euro Group. ${ }^{1}$

The judgment of the Court was delivered in cases C-603/18 P and C-604/18 P, Chrysostomides et al. and Bourdouvali et al. v Council, Commission, ECB and Euro Group, where the applicants appealed against the judgments of the General Court in Cases T-680/13 and T-786/14, Chrysostomides et al. $v$ Council et al., and Bourdouvali et al. $v$ Council et al., respectively, for dismissing the claim that the Council et al. were responsible for the losses they incurred in 2013 when the largest bank in Cyprus was restructured and the second-largest bank was wound down. ${ }^{2}$ The same judgment covered cases C-597/18 P \& C-598/18 P, Council v Chrysostomides et al., \& Council v Bourdouvali et al., where the Council appealed against the same judgments of the General Court for finding that the actions of Chrysostomides et al. and Bourdouvali et al. were admissible.

The cases are complex and the judgment of the Court of Justice dealt with several issues. Therefore, it is necessary at the outset to make clear to the reader that this article focuses only on the part of the judgment concerning the status of the Euro Group and the implications from the finding that it is not an EU institution or an entity established by the Treaties.

The narrow focus of this article does not mean that other issues are less important. For example, ever since its judgment in Pringle, ${ }^{3}$ the Court of Justice has been praised for either interpreting the TFEU teleologically and inventively ${ }^{4}$ or, by contrast, has been criticized for being too timid to oppose the actions of Member States ${ }^{5}$ and for not holding EU institutions such as the European Central Bank sufficiently accountable. ${ }^{6}$ The common thread in all this analysis and commentary on the judgments of the Court is how to interpret the Treaties. When one takes sides on these important issues, one explicitly or implicitly has in mind the 'correct' or 'desired' interpretation of primary or secondary law. In this article I do not propose any new method of interpretation. Whether the Euro Group is an entity established by the Treaties hinges on how one understands the word 'established' and its meaning in the context of the Treaties. Rather my objective is to point out that, ironically, the Court appears to have weakened the very judicial protection it

1. For a critical assessment of the part of the judgment on Euro Group, see M. Markakis and A. Karatzia, The Final Act on the Euro Group and Effective Judicial Protection in the EU: Chrysostomides, EU Law Live, 22 December 2020. It can be accessed at: https:/eulawlive.com/op-ed-the-final-act-on-the-eurogroup-and-effective-judicialprotection-in-the-eu-chrysostomides-by-menelaos-markakis-and-anastasia-karatzia/.

2. Joined Cases C-597/18 P, C-598/18 P, C-603/18 P and C-604/18 P, EU:C:2020:1028; T-680/13 Chrysostomides et al. v Council, Commission, ECB, Euro Group, EU:T:2018:486; Case T-786/14 Bourdouvali et al. v Council, Commission, ECB and Euro Group, EU:T:2018:487.

3. Case C-370/12 Pringle, EU:C:2012:756.

4. See, for example, P. Craig, 'Pringle, Legal Reasoning, Text, Purpose and Teleology', 20 Maastricht Journal of European and Comparative Law (2013), p. 3.

5. See, for example, G. Beck, 'The Legal Reasoning of the Court of Justice and the Euro Crisis - The Flexibility of the Court's Cumulative Approach and the Pringle Case', 20 Maastricht Journal of European and Comparative Law (2013), p. 635.

6. See, for example, M. Dawson, A. Maricut-Akbik and A. Bobic, 'Reconciling Independence and Accountability at the European Central Bank: The False Promise of Proceduralism', 25 European Law Journal (2019), p.75; Ch. Joerges, "Where the Law Runs Out": The Overburdening of Law and Constitutional Adjudication by the Financial Crisis and Europe's New Modes of Economic Governance', in S. Garben, I. Govaere and P. Nemitz (eds.), Critical Reflections on Constitutional Democracy in the European Union (Hart Publishing, 2019), p. 167, and the other contributions in the book. 
wanted to defend. The reader will have to decide whether that was inherent in the provisions of the Treaties or whether the Court had discretion to arrive at a different conclusion. I will argue that liability should not stop at those who formally decide but it should also extend to those who frame those decisions and make them inevitable.

\section{A brief review of the part of the judgment concerning the euro group}

First, it is worth recalling that the General Court held, in Cases T-680/13 and T-786/14, that the Euro Group was an EU institution. ${ }^{7}$ Even though the Court of Justice had found in Mallis that the Euro Group was not an a decision-making institution against which proceedings could be initiated under Article 263 TFEU $^{8}$ the General Court still concluded that it could be liable under Article 340 TFEU because 'non-decision-making conduct capable of giving rise to the noncontractual liability of the European Union can form the basis for an action for damages, although it cannot be the subject of an action for annulment' under Article 263 TFEU. ${ }^{9}$ The General Court considered the Euro Group to bear in principle non-contractual liability because, in its view, 'the Euro Group is a body of the Union formally established by the Treaties and intended to contribute to achieving the objectives of the Union. ${ }^{10}$ We will see below, however, that the Court of Justice faulted the General Court on this point.

The TFEU refers to the Euro Group only twice; in Article 137 and in Protocol 14. Article 137 TFEU provides that 'arrangements for meetings between ministers of those Member States whose currency is the euro are laid down by the Protocol on the Euro Group.' Protocol 14 attached to the TFEU lays down rules for the meetings of the Euro Group, even though Article 1 of the Protocol clarifies that the Euro Group 'shall meet informally'.

The Court of Justice began its analysis in cases C-597/18 P, C-598/18 P, C-603/18 P and C-604/ $18 \mathrm{P}$, by explaining that Article 340(2) TFEU establishes the non-contractual liability of the EU when damage is caused by its institutions or its servants in the performance of their duties. In order for the EU to incur non-contractual liability, three conditions must be satisfied: (i) the conduct of the EU or its servants must be unlawful, (ii) damage must be suffered by a third party and (iii) there must be a causal link between that conduct and the damage. ${ }^{11}$ In order to avoid unnecessary repetition, from now on all references are to the judgment of the Court of Justice of 16 December 2020, unless otherwise stated.

Then the Court turned its attention to the meaning of the term 'institution' in Article 340(2) TFEU. The Court reiterated the established principle that '(80) the term 'institution' within the meaning of that provision encompasses not only the EU institutions listed in Article 13(1) TEU but also all the EU bodies, offices and agencies that have been established by or under the Treaties and are intended to contribute to the achievement of the European Union's objectives'.

\footnotetext{
7. For the purposes of this article the findings of the General Court in Chrysostomides and Bourdouvali are similar. For a review of the judgment in Chrysostomides, see M. Krika, 'Annotation of Case T-680/13, Chrysostomides, K. \& Co and Others $v$ Council and Others, 1 Hellenic Review of European Law (2019), p. 75. It can be accessed at: www.cieel.gr/en/ magazine $/ 2019-\%$ cf $\% 80 \%$ cf $\% 81 \%$ cf $\% 8$ e $\%$ cf $\% 84 \%$ ce $\%$ bf- $\%$ cf $\% 84 \%$ ce $\%$ b5 $\%$ cf $\% 8 d \%$ cf $\% 87 \%$ ce $\%$ bf $\%$ cf $\% 82 /$.

8. Joined Cases C-105/15 P to C-109/15 P Mallis et al. v Commission and ECB, EU:C:2016:702, para. 61.

9. Case T-680/13 Chrysostomides, para. 110 and Case T-786/14 Bourdouvali, para. 106.

10. Ibid., para. 113 .

11. Paragraphs 78 \& 79 of the judgment in Cases C-597/18 P, C-598/18 P, C-603/18 P and C-604/18 P.
} 
In this connection, the Council argued that the General Court erred in law because the Euro Group was not established by the Treaties, even though Article 137 TFEU and Protocol 14 provided for informal meetings without conferring any competence to the Euro Group.

The Court of Justice noted that the Euro Group was established on 13 December 1997 by a resolution of the European Council as '(84) an intergovernmental body - outside the institutional framework of the European Union'.

Although Article 137 TFEU and Protocol 14 provide for the existence, the composition, the procedural rules and the functions of the Euro Group, the Court of Justice held that, for three reasons, '(86) it cannot be inferred...that the Euro Group is an EU entity established by the Treaties'. First, '(87) Article 137 TFEU and Protocol No 14...did not alter its intergovernmental nature in the slightest.' Second, '(88) the Euro Group is characterised by its informality'. Third, '(89) the Euro Group does not have any competence of its own in the EU legal order'.

In paragraph 90, the Court of Justice concluded that the General Court was wrong to find that the Euro Group was an EU body established by the Treaties. It is, however, difficult to follow the reasoning of the Court of Justice on this point as it is not obvious why its intergovernmental nature, its informality and the absence of formal competence imply that it was not established by the Treaties. Perhaps the Court of Justice meant that the Euro Group was not created by the Treaties, despite the fact that it was given a role by the Treaties, albeit informal.

Then the Court of Justice went on to address the main issue concerning liability. Despite the fact that agreements within the Euro Group could not lead to non-contractual liability, as it was not an institution in the meaning of Article 340 TFEU, individuals were not deprived of effective judicial protection against such agreements. According to the Court of Justice, given

(93) the fact that the Euro Group does not have the power to punish a failure to comply with the political agreements concluded within it, those agreements are given concrete expression and are implemented by means, in particular, of acts and action of the EU institutions. Individuals may thus bring before the EU judicature an action to establish non-contractual liability of the European Union against the Council, the Commission and the ECB in respect of the acts or conduct that those EU institutions adopt following such political agreements.

Thus, individuals could seek redress by proving the illegality of subsequent acts that gave effect to agreements within the Euro Group.

With respect to the Commission, the Court pointed out that

(96) as is apparent from Article 17(1) TEU, the Commission 'shall promote the general interest of the Union' and 'shall oversee the application of Union law' [here it cited Pringle, para 163, and Ledra Advertising v Commission and ECB, para 57]. ${ }^{12}$ It therefore retains, in the context of its participation in the activities of the Euro Group, its role of guardian of the Treaties. It follows that any failure on its part to check that the political agreements concluded within the Euro Group are in conformity with EU law is liable to result in non-contractual liability of the European Union being invoked under the second paragraph of Article 340 TFEU.

12. Case C-370/12 Pringle; and Joined Cases C-8/15 P to C-10/15 Ledra Advertising et al. v Commission and ECB, P EU: $\mathrm{C}: 2016: 701$. 
However, the Court did not explain how the Commission could be liable for failing to prevent the Euro Group from concluding an agreement contrary to EU law, given that the Euro Group was held not to be an EU institution. If, as a consequence, it fell outside the jurisdiction of the Court of Justice, how could the Commission initiate action, for example, on the basis of Articles 258 or 263 TFEU? Interestingly, in paragraph 93 of the judgment, the Court referred to the fact that the Euro Group did not have 'the power to punish' non-compliance. By the same token, it is not obvious how the Commission could wield any power over the Euro Group. We will return to the implications of this part of the judgment in the next section. One of the referees commented at this point that theoretically the Commission could, instead, launch infringement proceedings against one or several Member States if they acted contrary to primary or secondary legislation. Although indeed this remains a theoretical possibility, the question in practice is how to prove that the outcome of a Euro Group agreement is attributed to Member States when, as we will see below, the Member State that carries out the bail-in is considered to exercise discretion.

Then the Court examined the plea of the Council that the General Court was wrong in holding that, as a result of Article 2(6)(b) of Council Decision 2013/236, the Cypriot authorities had no margin of discretion when they bailed in the shareholders and creditors of the two Cypriot banks. It is this bail-in that caused harm to the applicants. Council Decision 2013/236 gave effect to the political agreement in the Euro Group. ${ }^{13}$

The Court of Justice first explained in paragraph 106 that damage caused by national authorities fell outside the scope of Articles 268 [granting jurisdiction to the Court of Justice to award compensation for damages] and 340(2) TFEU. For this reason, '(107) in order to determine whether the EU judicature has jurisdiction, it must be established whether the unlawful conduct alleged in support of the claim for compensation is truly the responsibility of an EU institution and cannot be regarded as attributable to a national authority.'

The Court recalled at the outset that

(109) Article 2(6)(b) of Decision 2013/236 states that the macroeconomic adjustment programme for the Republic of Cyprus is to provide for 'establishing an independent valuation of the assets of [Bank of Cyprus] and [Laïki Bank] and quickly integrating the operations of [Laiiki] into [Bank of Cyprus]. The valuation shall be completed quickly so as to enable the completion of the deposit-equity swap at [Bank of Cyprus]'.

Then it found that the General Court correctly concluded that '(110) the Council, "by means of Article 2(6)(b) of Decision 2013/236, required the Republic of Cyprus to maintain or continue to implement...the conversion of uninsured deposits in BoC into shares".'

(114) Second, the General Court verified... whether the Republic of Cyprus had a margin of discretion to escape the requirement to maintain or continue to implement the conversion of the uninsured deposits in BoC into shares. The General Court explained first of all...that Decision 2013/236 was mandatory for the Republic of Cyprus in its entirety, including Article 2(6)(b) thereof, as its provisions are entirely worded in mandatory terms. Next,...it stated that that decision was intended to produce legally binding effects. Finally,...the General Court observed that the Council had stated...that Decision 2013/236 reflected a common practice that had developed since the beginning of the euro area crisis,

13. Council Decision 2013/236 of 25 April 2013 addressed to Cyprus on specific measures to restore financial stability and sustainable growth, [2013] OJ L 141/32. 
under which conditionality attached to financial assistance granted to an MSCE is coupled with Council decisions based on Article 136 TFEU, thereby ensuring consistency between the intergovernmental and EU spheres of action. It concluded therefrom...that the Republic of Cyprus had no margin of discretion to revoke the conversion of the uninsured deposits in $\mathrm{BoC}$ into shares.

However, the Court of Justice declared the reasoning of the General Court to be '(115) vitiated by an error of law' and in a short paragraph it explained that

(116) Article 2(6)(b) of Decision 2013/236 merely requires, in general terms, that the Cypriot authorities maintain or continue to implement the conversion, without defining in any way the specific rules for that operation.... The General Court was wrong in concluding...that the Cypriot authorities had no margin of discretion for the purpose of laying down such rules, in particular for the purpose of determining the number and value of the shares to be allocated to BoC's depositors in exchange for their uninsured deposits with that bank.

On the basis of the above review, it is fair to summarize the conclusions of Court of Justice in this part of its judgment in the following three statements:

1. The Euro Group is not an institution or body established by the Treaties and therefore not subject to Article 340 for non-contractual liability. It remains outside EU law, just like the Court ruled in Pringle concerning the European Stability Mechanism.

2. Individuals harmed by an agreements concluded within the Euro Group may bring a claim against the Council when it gives effect to such an agreement with a decision of its own or against the Commission for failing to prevent the conclusion of the agreement in the Euro Group.

3. The Council can be liable only when its decision deprives a Member State from any discretion.

In the rest of the judgment, the Court of Justice confirmed the ruling in Ledra Advertising that the right to property was not absolute and that it could be limited by measures to protect financial stability. The principle of protection of legitimate expectations was not infringed by EU institutions which had not given any specific and unconditional assurances to the applicants, nor was it violated by changes in the EU's response to the unfolding financial crisis. The fact that bonds held by the ECB were not bailed in did not compromise the principle of equal treatment because the applicants, as investors and depositors, were not in a comparable situations as the ECB which acted in the public interest.

In the end the Court of Justice set aside the judgment of the General Court concerning the Euro Group and upheld the rest of it.

\section{An assessment}

The purpose of this section is to identify two weaknesses in the reasoning of the Court of Justice in the part of its judgment in paragraphs 79-116 that examines whether the Euro Group is an EU 'institution' liable for non-contractual liability. ${ }^{14}$ As explained in the introduction of this article, other issues and other potential weaknesses are not considered here. 


\section{Causality and discretion}

The first weakness concerns the causality between the decision of the Council and the actions of the Cypriot authorities. The Court found that the Cypriot authorities had a margin of discretion and for this reason it held that the General Court was wrong in concluding that the Cypriot authorities had no margin of discretion.

At first glance, the Court of Justice appears to be right. The Cypriot authorities did have a choice of how to implement the conversion of uninsured deposits into shares.

However, the Court of Justice failed to make a fundamental distinction between discretion as to the extent and form of the conversion and discretion as to whether the conversion had to be effected at all in one form or another.

Please note that the General Court found that 'Cyprus had no margin of discretion to revoke the conversion'; that is, whether the conversion took place. It did not refer to the valuation of the conversion. But the Court of Justice faulted the General Court on the grounds that Cyprus did have discretion 'for the purpose of determining the number and value of the shares to be allocated to BoC's depositors'. The two courts referred to different aspects of the conversion.

If the Cypriot authorities could not avoid conversion then the act of converting deposits into shares, regardless of the valuation of the shares, had to be attributed to the decision of the Council.

Then the Court of Justice should have examined whether Cyprus, within the margin of discretion it could exercise, could avoid inflicting losses on the applicants. The fact that Cyprus had a certain margin of discretion in the valuation of the shares and in the process of conversion of uninsured deposits into shares does not prove that it was possible for it to identify some valuation and some form of conversion that would not involve any bail-in. Since the Bank of Cyprus experienced losses that exceeded its capital [shares and bonds], the conversion of deposits into shares would unavoidably result in some losses for the uninsured depositors. It was even more necessary to inflict losses on the shareholders and creditors of Laïki Bank which was insolvent.

As is evident from the statement of the Euro Group of 25 March 2013, which is reproduced in the Annex at the end of this article, the purpose of the conversion of the deposits into shares was to minimize the amount of financial assistance that was granted to Cyprus. This indeed may be a legitimate policy objective and the right approach to address the issue of moral hazard. But it does not relieve the Council from responsibility for its decision.

The crux issue here is how far liability should be extended. The Cypriot government decided the details of the bail-in. But was the bail-in avoidable? Should the Council and the Euro Group not share responsibility if their decisions made the bail-in unavoidable? This kind of reasoning in

14. On the broader issues of the accountability and liability of EU institutions in the area of monetary policy see D. Adamski, 'Judicial Review of Economic and Financial Governance MoUs - Between Legal Impeccability and Economic Flaws', in Building Bridges: Central Banking Law in an Interconnected World, ECB Legal Conference December 2019. It can be accessed at: www.ecb.europa.eu/pub/pdf/other/ecb.ecblegalconferenceproceedings201912 9325c45957.en.pdf? $258 \mathrm{~d} 648 \mathrm{ffcf} 1 \mathrm{be} 39 \mathrm{f} 9 \mathrm{~d} 927 \mathrm{e} 5 \mathrm{c} 13 \mathrm{f} 393 \mathrm{f}$. He argues that it is in practice impossible to win a case against [the ECB] before the Court of Justice in Luxembourg. ... while legally unchallengeable before the European top court, strict conditionality MoUs are profoundly baffling nonetheless, especially in the euro area' (ibid., p. 263). See also P. Dermine, 'Out of the Comfort Zone? The ECB, Financial Assistance, Independence and Accountability', 26 Maastricht Journal of European and Comparative Law (2019), p. 108; R. Smits, 'Accountability of the European Central Bank', Ars Aequi, January 2019, www.speakersacademy.com/wp-content/uploads/2018/06/ Accountability-of-the-European-Central-Bank.pdf; N. Xanthoulis, 'ESM, Union Institutions and EU Treaties: A Symbiotic Relationship (Joint Cases C-8/15 P to C-10/15 P (Ledra Advertising Ltd et al.) and Joint Cases C-105/15 P to C-109/15 P (Mallis and Malli et al.)', 1 International Journal for Financial Services (2017), p. 21. 
terms of possible counterfactuals is not alien to the EU and its judicature. For example, damages caused by cartels are established by asking what would have happened 'but for' the cartel. ${ }^{15}$ In the case of Cyprus, was there a credible counterfactual that did not include a bail-in? In other words, was there any other option for Cyprus in the context of the Council decision that did not involve a bail-in? If the answer is no, then it seems to me that the Council would also have to bear responsibility.

\section{Effective judicial protection against agreements in the Euro Group?}

The second weakness of the part of the judgment that is examined in this article is the vagueness of the Court's treatment of judicial protection. ${ }^{16}$ The Court of Justice held that even though the Euro Group was not an EU 'institution' for the purposes of Art 340 TFEU, individuals could still avail themselves of effective judicial protection in two indirect ways. First, political agreements within the Euro Group had to be given effect in decisions of the Council. So the Council could be liable. Second, the Commission, as the guardian of the Treaties, could 'check' whether those agreements were in conformity with EU law. So the Commission could be liable.

With respect to the first means of protection of individuals via the liability of the Council, the Court of Justice ignored the possibility that not everything that was agreed in the Euro Group necessarily had to be written in a Council decision. Consider the following scenario with the following three options for a country that is a Member of the Eurozone and experiences a severe financial crisis that forces it to negotiate the terms of financial assistance:

1. If there is no agreement within the Council, it suffers a loss of 3.

2. If there is agreement within the Council on $\mathrm{X}$ amount of aid and $\mathrm{Y}$ number of obligations, it suffers a loss of 2 [call this decision A].

3. If there is agreement within the Euro Group offering more aid $[\mathrm{X}+]$ linked to extra obligations $[\mathrm{Y}+]$ which, however, are not made formal in a Council decision [call this decision B, not containing the extra obligations], it suffers a loss of 1 .

The extra obligations may concern more stringent reporting obligations to the EU or closer scrutiny and prior approval of any measures by the EU or more extensive reform or, as in the case of Cyprus, a requirement to inflict losses on large depositors. Indeed, at the time of the banking crisis was unfolding in Cyprus in Winter 2012 - Spring 2013, it was not legally clear whether bail-in of depositors were compatible with the Treaty and especially with the right to property enshrined in Article 17 of the Charter of Fundamental Rights. ${ }^{17}$ The Euro Group could have agreed that shareholders and depositors had to be bailed in to the largest possible extent, but took care to use more

15. See recital 47 of Directive 2014/104 on certain rules governing actions for damages under national law for infringements of the competition law provisions of the Member States and of the European Union, OJ L 349/1: 'cartels result in a rise in prices, or prevent a lowering of prices which would otherwise have occurred but for the cartel'. See also, for example, para. 30 of the judgment in Case C-557/12 Kone, EU:C:2014:1317, 'a loss being suffered by the customer of an undertaking not party to a cartel, but benefiting from the economic conditions of umbrella pricing, because of an offer price higher than it would have been but for the existence of that cartel is one of the possible effects of the cartel'.

16. For a review of the concept of judicial protection see G. Gentile, 'Ensuring Effective Judicial Review of EU Soft Law via the Action for Annulment before the EU Courts: a Plea for a Liberal-Constitutional Approach', 16 European Constitutional Law Review (2020), p. 466. 
innocuous terms in the corresponding Council decision and to define the obligations of Cyprus as commitments 'voluntarily' accepted by Cyprus. In fact Article 2(6)(b) of Council Decision 2013/ 356 is expressed in very general terms: 'The valuation shall be completed quickly so as to enable the completion of the deposit-equity swap at Bank of Cyprus'.

If the three options above are the only options available to a country experiencing a severe financial crisis, it is possible that it may accept more stringent obligations and greater external scrutiny of its economic management in order to obtain a larger amount of aid and avoid an economic meltdown.

What legal redress is available to individuals in this situation under EU law? Since the decision of the Council does not impose explicit and precise obligations, it cannot be held liable. An interesting question is whether Council decisions would have been more precise had the Euro Group not existed. Perhaps they would if the Euro Group enables Member States to discuss and agree on details that they do not want recorded in Council decisions. Perhaps, on the other hand, if the Euro Group did not exist, such details could still be agreed informally in the margins of Council meetings. We cannot know how the Council would have acted in the absence of the Euro Group. However, the Court of Justice did not have in front of it a hypothetical situation but the actual Council decisions. The question for the Court was how individuals could obtain redress, given the vagueness of Council decisions.

Individuals can, of course, resort to national courts. In practice, however, they are unlikely to receive compensation from a depleted national treasury, even if they can prove state liability. But, more importantly, state liability is elusive here too. The national government will argue, as the Cypriot government has done successfully, that the bail-in is a decision of the boards of the banks themselves. They cannot fault a board for choosing to offer them shares in exchange for their deposits instead of allowing the bank to go bankrupt and lose all their money.

Ultimately, shareholders are in a no-win situation because there is no obligation under EU law or national law to compensate them. Depositors in failing banks are in a similar situation for losses they incur above the threshold of insured deposits of EUR 100,000. In other words, Members of the Eurozone have no obligation to bail out shareholders and creditors.

The point here, however, is that the Council decision need not contain explicitly all of the obligations imposed on a Member State and for this reason they escape from the jurisdiction of the Court of Justice. As the Court itself has made clear, the Euro Group, where deals are actually agreed, is not an EU institution. It is an intergovernmental body.

With respect to the second means of protection of individuals via the liability of the Commission, the question that has not been addressed by the Court is how the Commission, as the guardian of the Treaties, can prevent the Euro Group from cooking up a deal that may infringe EU law. The Commission may be able to initiate proceedings against the Council. But as argued above, it is possible that the Council decision is drafted in a manner that does not cause it to violate EU law. The Euro Group is not an EU institution and the agreements of Member States in the context of Euro Group meetings are not formal decisions actionable under Article 263 TFEU. Still, as mentioned earlier, the Commission may initiate action against individual Member States. But it will have to prove that any decision is attributed to them. Given that, as we saw, such decisions leave apparent

17. Directive 2014/59 on bank recovery and resolution was adopted on 15 May 2014. Regulation $806 / 2014$ on the Single Resolution Mechanism was adopted on 15 July 2014. The Commission's Banking Communication was adopted on 10 July 2013. 
discretion to the Member State imposing the bail-in, it must be a very difficult task to prove the culpability of individual Member States. The Commission cannot be held liable if it is impossible for it to act.

The Court of Justice declared but did not prove that it would be possible for individuals to seek judicial protection via possible liability of the Council or Commission, as a consequence of ruling that the Euro Group was not an EU 'institution' or 'body' for the purposes of Article 340 TFEU.

Before concluding this article it is necessary to ask why a Member State such as Cyprus felt compelled to act the way it acted, given the apparent discretion afforded to it by the Council decision. I believe the answer is simple and can be expressed in two words: 'no money'. Its apparent discretion was illusory. Since it was practically cut off from the international financial markets, it had to inflict losses on shareholders, bondholders and depositors. The amount of losses were inversely proportional to the amount of assistance the other Member States were willing to grant it. Decisions are not taken in a vacuum. They are always taken in a given context. The Court focused on the Cypriot decision and somehow did not see it relevant to examine what prompted the Cypriot government to act in the way it acted. In criminal law those who supply the gun are as liable as those who pull the trigger.

\section{Conclusions}

The Court of Justice made legal history in Ledra Advertising when it found that the EU could incur non-contractual liability even for acts that formally fell within the intergovernmental sphere. ${ }^{18}$ In Chrysostomides, however, by ruling that the Euro Group is not an EU 'institution', the Court has made it largely impossible for individuals to obtain judicial protection. The decisions of the Council that give effect to agreements in the Euro Group can be drafted in innocuous and general language. The powers of the Commission to act against such agreements in the Euro Group are also unclear and probably non-existent.

\section{Annex: A comparison of Council Decision 2013/236 and the Euro Group statement of 25 March 2013}

Council Decision 2013/236 lists the many different policy areas that Cyprus needed to reform and the many actions it had to take to kick-start its economy. The part of the Decision that referred to the bail-in of uninsured depositors was brief. Article 2(6) of the Decision provides the following:

With a view to restoring the soundness of its financial sector, [the Republic of Cyprus] shall continue to thoroughly reform and restructure the banking sector and reinforce viable banks by restoring their capital, addressing their liquidity situation and strengthening their supervision. The programme shall provide for the following measures and outcomes:

18. Joined Cases C-8/15 P to C-10/15 Ledra Advertising et al. v Commission and ECB, P, EU:C:2016:701. 
(b) establishing an independent valuation of the assets of Bank of Cyprus and Cyprus Popular Bank and quickly integrating the operations of Cyprus Popular Bank into Bank of Cyprus. The valuation shall be completed quickly so as to enable the completion of the deposit-equity swap at Bank of Cyprus. [The Cyprus Popular Bank was also known as Laïki Bank].

Now contrast the brevity and the rather general and non-specific language of Article 2(6)(b) with the Euro Group statement of 25 March 2013. The text of the statement is reproduced in paragraphs 16-18 of the judgment of the Court of Justice:

There will be an appropriate downsizing of the financial sector.

The following was agreed:

1. [Cyprus Popular Bank Public Co.] will be resolved immediately - with full contribution of equity shareholders, bondholders and uninsured depositors - based on a decision by the Central Bank of Cyprus, using the newly adopted Bank Resolution Framework.

2. [Cyprus Popular Bank Public Co.] will be split into a good bank and a bad bank. The bad bank will be run down over time.

3. The good bank will be folded into [Trapeza Kyprou Dimosia Etaireia], using the Bank Resolution Framework, after having heard the Boards of Directors of [Trapeza Kyprou Dimosia Etaireia] and [Cyprus Popular Bank Public Co.]. It will take [EUR 9 billion] of [emergency liquidity assistance] with it. Only uninsured deposits in [Trapeza Kyprou Dimosia Etaireia] will remain frozen until recapitalisation has been effected, and may subsequently be subject to appropriate conditions.

5. [Trapeza Kyprou Dimosia Etaireia] will be recapitalised through a deposit/equity conversion of uninsured deposits with full contribution of equity shareholders and bondholders.

8. The programme money (up to [EUR 10 billion]) will not be used to recapitalise [Cyprus Popular Bank Public Co.] and [Trapeza Kyprou Dimosia Etaireia]. [emphasis added] [Trapeza Kyprou is the Bank of Cyprus]

It is now rather obvious that the language used in the agreement in the Euro Group is more specific and hardly leaves any room for manoeuvre to Cyprus with respect to the bail-in of uninsured depositors. The uninsured depositors of Popular Bank suffered a steep haircut, perhaps losing all of their money above EUR 100,000. The uninsured depositors also lost money in the conversion of their deposits into shares of uncertain value bearing risk. In the case of the latter, the only unknown factor was the extent of the conversion. Cyprus was not given a choice not to bail in uninsured depositors. This is not where it could exercise discretion. In fact its real choices were further constrained by the prohibition of using programme money (i.e. ESM money) to recapitalise the two 
banks. Since it did not have enough of its own money to rescue the banks and had to borrow money from the ESM, the bail-in of depositors was inevitable.

A reviewer observed that the Council decision uses the word 'shall' which is more binding than the word 'will' in the Euro Group statement and asked whether Cyprus could ignore the Euro Group. I think that was impossible. The money would not have been released by the ESM. In fact this exercise of trying to figure out what could have otherwise happened shows that Cyprus had no other viable option but to inflict losses on shareholders and creditors. Even though one could blame the ESM, the fact remains that Member States also acted within the Council, which could escape liability under the pretext that the decisions that inflicted losses were taken by a Member State.

\section{Acknowledgements}

I am grateful to Julio Baquero Cruz and Menelaos Markakis for comments and suggestions on an earlier draft.

\section{Declaration of Conflicting Interests}

The author(s) declared no potential conflicts of interest with respect to the research, authorship, and/or publication of this article.

\section{Funding}

The author(s) received no financial support for the research, authorship and/or publication of this article.

\section{ORCID iD}

Phedon Nicolaides (DD https://orcid.org/0000-0003-3660-6891 